\title{
Insulin-Like Growth Factor Receptor
}

National Cancer Institute

\section{Source}

National Cancer Institute. Insulin-Like Growth Factor Receptor. NCI Thesaurus. Code

C17530.

The protein on surface of target cells specific for binding IGF. There are two types of IGF receptor, one of which closely resembles the insulin receptor. 